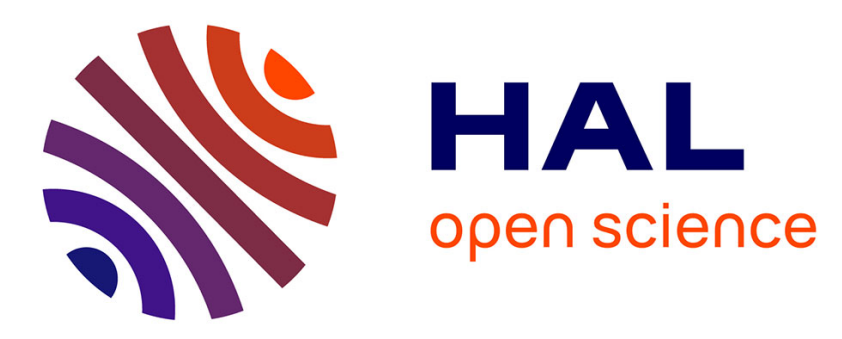

\title{
Model membrane approaches to determine the role of calcium for the antimicrobial activity of friulimicin
}

\author{
Katrin Reder-Christ, Hildegard Falkenstein-Paul, Gabriela Klocek, Saad
} Al-Kaddah, Udo Bakowsky, Gerd Bendas

\section{- To cite this version:}

Katrin Reder-Christ, Hildegard Falkenstein-Paul, Gabriela Klocek, Saad Al-Kaddah, Udo Bakowsky, et al.. Model membrane approaches to determine the role of calcium for the antimicrobial activity of friulimicin. International Journal of Antimicrobial Agents, 2011, 37 (3), pp.256. 10.1016/j.ijantimicag.2010.11.024 . hal-00671247

\section{HAL Id: hal-00671247 \\ https://hal.science/hal-00671247}

Submitted on 17 Feb 2012

HAL is a multi-disciplinary open access archive for the deposit and dissemination of scientific research documents, whether they are published or not. The documents may come from teaching and research institutions in France or abroad, or from public or private research centers.
L'archive ouverte pluridisciplinaire HAL, est destinée au dépôt et à la diffusion de documents scientifiques de niveau recherche, publiés ou non, émanant des établissements d'enseignement et de recherche français ou étrangers, des laboratoires publics ou privés. 


\section{Accepted Manuscript}

Title: Model membrane approaches to determine the role of calcium for the antimicrobial activity of friulimicin

Authors: Katrin Reder-Christ, Hildegard Falkenstein-Paul, Gabriela Klocek, Saad Al-Kaddah, Udo Bakowsky, Gerd Bendas

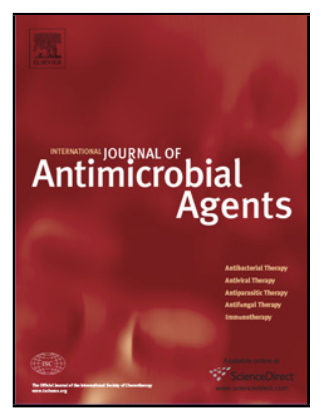

PII: S0924-8579(10)00540-6

DOI:

Reference: doi:10.1016/j.ijantimicag.2010.11.024

ANTAGE 3497

To appear in: International Journal of Antimicrobial Agents

Received date: $\quad 14-10-2010$

Revised date: $\quad$ 5-11-2010

Accepted date: $\quad 12-11-2010$

Please cite this article as: Reder-Christ K, Falkenstein-Paul H, Klocek G, Al-Kaddah S, Bakowsky U, Bendas G, Model membrane approaches to determine the role of calcium for the antimicrobial activity of friulimicin, International Journal of Antimicrobial Agents (2010), doi:10.1016/j.ijantimicag.2010.11.024

This is a PDF file of an unedited manuscript that has been accepted for publication. As a service to our customers we are providing this early version of the manuscript. The manuscript will undergo copyediting, typesetting, and review of the resulting proof before it is published in its final form. Please note that during the production process errors may be discovered which could affect the content, and all legal disclaimers that apply to the journal pertain. 


\section{Model membrane approaches to determine the role of calcium for the antimicrobial activity of friulimicin}

Katrin Reder-Christ ${ }^{\mathrm{a}, \star}$, Hildegard Falkenstein-Paul ${ }^{\mathrm{a}}$, Gabriela Klocek ${ }^{\mathrm{b}}$, Saad AlKaddah $^{\text {a }}$, Udo Bakowsky ${ }^{\mathrm{c}}$, Gerd Bendas ${ }^{\text {a }}$

a Department of Pharmacy, Rheinische Friedrich-Wilhelms-Universität Bonn, An der Immenburg 4, 53121 Bonn, Germany

${ }^{\mathrm{b}}$ Biophysical Chemistry, Biozentrum, University of Basel, Klingelbergstrasse 50/70, CH-4056 Basel, Switzerland

${ }^{c}$ Department of Pharmacy, Philipps-Universität Marburg, Ketzerbach 63, 35032 Marburg, Germany

\section{ARTICLE INFO}

Article history:

Received 14 October 2010

Accepted 12 November 2010

Keywords:

Cyclic lipopeptides

Atomic force microscopy

Biosensor

C55-P

Friulimicin 
* Corresponding author. Tel.: +49 228735 217; fax: +49 228734692.

E-mail address: kchrist@uni-bonn.de (K. Reder-Christ). 


\section{ABSTRACT}

Friulimicin is a cyclic lipopeptide antibiotic, currently in clinical development, that possesses excellent activity against Gram-positive bacteria, including multiresistant strains. A recent study on the mode of action of friulimicin reported on the interference with bacterial cell wall biosynthesis via a calcium-dependent complexing of the bactoprenol phosphate carrier $\mathrm{C}_{55}-\mathrm{P}$. The calcium dependency of this noncommon targeted activity remains to be elucidated. In the present model membrane approach, the role of calcium for friulimicin targeting to $\mathrm{C}_{55}-\mathrm{P}$ was investigated by biosensor-based detection of binding affinities. The findings were supplemented by atomic force microscopy (AFM) and circular dichroism (CD) spectroscopy. Comparing the calcium salt of friulimicin with the calcium-free peptide, calcium appeared to be essential for friulimicin interaction with 1,2-dioleoyl-sn-glycero-3phosphocholine (DOPC) model membranes. The binding affinity was even higher in the presence of $0.1 \mathrm{~mol}^{2} \mathrm{C}_{55}-\mathrm{P}(0.21 \mu \mathrm{M}$ vs. $1.22 \mu \mathrm{M})$, confirming the targeted mode of action. Binding experiments with supplemented calcium salts suggest (i) the phosphate group as the essential moiety of $\mathrm{C}_{55}-\mathrm{P}$, referring to a bridging function of calcium between the negatively charged friulimicin and $\mathrm{C}_{55}-\mathrm{P}$, and (ii) a structural effect of calcium shifting the peptide into a suitable binding conformation (CD spectra). AFM images confirmed that calcium has no, or only a minor, effect on the aggregate formation of friulimicin. These data shed new light on the mechanisms of antibacterial activity of friulimicin. 


\section{Introduction}

Friulimicin is a cyclic lipopeptide antibiotic isolated from Actinoplanes friuliensis [1] and is active against many Gram-positive bacteria, including antibiotic-resistant strains, e.g. meticillin-resistant Staphylococcus aureus (MRSA) [2]. It is currently in clinical development and is a promising drug candidate. Friulimicin consists of a cyclic decapeptide that is $N$-terminally linked to an unsaturated branched fatty acid (Fig. 1A) [1].

Despite variations in the length and branch of the fatty acids as well as in the number of amino acid residues, all cyclic lipopeptides share amphipathic characteristics. The lipid side chain and hydrophobic amino acid residues are balanced by the overall net negative charge of the lipopeptides, making them highly soluble in aqueous solution [3]. The macrocycle possesses three amino acid residues that are conserved in all cyclic lipopeptides and probably show a similar conformation that might be important for their activity.

However, the mode of action of lipopeptides has not been fully elucidated so far. Most studies have been done with daptomycin, which received US Food and Drug Administration (FDA) approval in 2003. Its proposed mode of action derives from the interaction with bacterial membranes. Daptomycin aggregates in the presence of calcium. The resulting conformational changes induce an interaction with the bacterial membrane, a reduction of the membrane potential, leakage and cell death $[4,5]$. In recent studies, daptomycin was assumed to have an impact on the cell envelope integrity. It even might affect the lipid II cycle [6]. 
Despite its structural similarity to daptomycin, friulimicin has a different mode of action. Schneider et al. [7] recently showed that friulimicin complexes the bactoprenol phosphate carrier $\mathrm{C}_{55}-\mathrm{P}$ in a calcium-dependent manner and thus inhibits cell wall biosynthesis. Membrane integrity was not influenced [7]. Although the calciumdependency of friulimicin activity was shown, the role of calcium ions has yet to be clarified.

The present model membrane approach affords insights into the role of calcium in the mode of action of friulimicin and presents more details on targeting $\mathrm{C}_{55}-\mathrm{P}$. Detection of kinetic constants of friulimicin binding to $\mathrm{C}_{55}-\mathrm{P}$ in model membranes by quartz crystal microbalance (QCM) confirms that (i) the phosphate is the crucial moiety of the target structure $\mathrm{C}_{55}-\mathrm{P}$ and (ii) calcium is essential for friulimicin binding to $\mathrm{C}_{55}-\mathrm{P}$. Atomic force microscopy (AFM) and circular dichroism (CD) spectroscopy show that calcium has no, or only a minor, effect on peptide aggregate formation, but mediates a favourable conformation of the peptide molecules for binding $\mathrm{C}_{55}-\mathrm{P}$. These data reflect the results of Schneider et al. [7] referring to $\mathrm{C}_{55}-\mathrm{P}$ as the friulimicin target and, furthermore, shed new light on the processes at the bacterial membrane surface.

\section{Materials and methods}

\subsection{Chemicals}

All commercial reagents were of highest quality and were used without further purification. 1,2-Dioleoyl-sn-glycero-3-phosphocholine (DOPC) was purchased from Avanti Polar Lipids Inc. (Alabaster, AL). $\mathrm{C}_{55}-\mathrm{P}$ (undecaprenyl phosphate) was 
purchased from Larodan Fine Chemicals AB (Malmö, Sweden). Dicetylphosphate (DCP) was from Sigma (Deisenhofen, Germany). Friulimicin B (FRI) and calcium chloride-associated friulimicin B (FRI-CA) were kindly provided by Prof. Hans-Georg Sahl (Universität-Bonn, Bonn, Germany).

\subsection{Model membrane preparation}

Cleaning and preparation procedures of the quartz sensors for QCM have been described previously [8]. Preparation of microscope glass slides for AFM were described [9]. For both QCM and AFM, the supported bilayers were completed by transferring a monolayer consisting of either pure DOPC, DOPC $/ 0.1 \mathrm{~mol}^{2} \mathrm{C}_{55}-\mathrm{P}$ or DOPC/0.1 mol\% DCP by Langmuir-Blodgett technique onto the covalently fixed first monolayer.

\subsection{Quartz crystal microbalance experiments}

QCM experiments were performed at $25^{\circ} \mathrm{C}$ using a LiquiLab21 system (ifak e.V., Barleben, Germany). After reaching a constant frequency, $3 \mathrm{~mL}$ of a $1 \mu \mathrm{M}$ peptide solution was injected into the flow system. The run was stopped after reaching a constant frequency. Binding constants were calculated from the frequency traces as described previously [9].

\subsection{Atomic force microscopy experiments}

AFM images were obtained on a NanoWizard ${ }^{\circledR}$ (JPK Instruments, Berlin, Germany) and on a Digital NanoScope IV BioScope (Veeco Instruments, Santa Barbara, CA). Details have been described previously [9]. 


\subsection{Circular dichroism spectroscopy}

$\mathrm{CD}$ measurements of $\mathrm{FRI}, \mathrm{FRI}-\mathrm{CA}$ and pre-incubated friulimicin (FRI-PI) were taken at $25^{\circ} \mathrm{C}$ using a Chirascan ${ }^{\mathrm{TM}} \mathrm{CD}$ spectrometer (Applied Photophysics Ltd., Leatherhead, UK). A quartz cuvette with a path length of $0.1 \mathrm{~cm}$ was used. Scans were obtained at $0.5 \mathrm{~nm}$ resolution, $1 \mathrm{~nm}$ bandwidth and at a scan speed of $7 \mathrm{~s}$ per point. All spectra were measured in water and were corrected by subtracting the baseline. Results are reported as mean residue ellipticity in units of deg $\mathrm{cm}^{2} \mathrm{dmol}^{-1}$.

\section{Results and discussion}

\subsection{Friulimicin binding depends on C55-P and peptide-associated calcium}

Binding to $\mathrm{C}_{55}-\mathrm{P}$ is not a common mode of action of antibiotics and has only been described so far for friulimicin. To confirm further this target process, the binding kinetics of friulimicin to DOPC \pm 0.1 mol\% $\mathrm{C}_{55}-\mathrm{P}$ model membranes using a $\mathrm{QCM}$ biosensor was analysed. Although bacterial membranes contain a certain fraction of negatively charged lipids, the non-charged DOPC was consciously selected as the matrix lipid to focus on the role of calcium in the interaction of the negatively charged friulimicin with $\mathrm{C}_{55}-\mathrm{P}$ and to avoid a charge-induced calcium accumulation at the membrane surface. Friulimicin was used either as calcium-free peptide (FRI) or associated with calcium chloride (FRI-CA) with two calcium ions per peptide molecule.

Fig. 1B illustrates the binding kinetics of both peptides in aqueous solution. In contrast to FRI, which did not show any binding, FRI-CA bound both to DOPC and 
$\mathrm{DOPC} / 0.1 \mathrm{~mol} \% \mathrm{C}_{55}-\mathrm{P}$ membranes. These findings give evidence for the general necessity of calcium in the friulimicin binding process.

The role of $\mathrm{C}_{55}-\mathrm{P}$ as the FRI-CA target could be confirmed. The binding affinity of FRI-CA to DOPC/ $5_{55}-\mathrm{P}$ was nearly six-fold higher than to pure DOPC membranes $\left(k_{D}=0.21 \mu \mathrm{M}\right.$ vs. $\left.1.22 \mu \mathrm{M}\right)$, reflecting the recent findings on the role of $\mathrm{C}_{55}-\mathrm{P}$ as the target for interference with cell wall biosynthesis. The FRI-CA association remains unaffected by the presence of $\mathrm{C}_{55}-\mathrm{P}$. Thus, the overall better binding to $\mathrm{DOPC} / \mathrm{C}_{55}-\mathrm{P}$ is mainly due to a nearly five-fold decelerated dissociation rate $\left(k_{\text {diss }} 0.75 \mathrm{E}^{-3} \mathrm{~s}^{-1} \mathrm{vs}\right.$. $\left.3.57 \mathrm{E}^{-3} \mathrm{~s}^{-1}\right)$.

\subsection{The phosphate moiety of C55-P dominates friulimicin binding}

QCM data confirmed the target function of $\mathrm{C}_{55}-\mathrm{P}$ and the general need of calcium for friulimicin binding. The role of calcium might be explained by a bridging function between the negatively charged peptide and the phosphate moiety of $\mathrm{C}_{55}-\mathrm{P}$. To focus further on the role of phosphate, $\mathrm{C}_{55}-\mathrm{P}$ was replaced by dicetylphosphate (DCP), which also possesses a phosphate moiety at the membrane surface but is membrane-anchored by two hexadecylalkane chains. Nearly identical binding affinities of $\mathrm{FRI}-\mathrm{CA}$ to $\mathrm{DOPC} / \mathrm{C}_{55}-\mathrm{P}$ and $\mathrm{DOPC} / \mathrm{DCP}$ could be obtained $\left(\mathrm{k}_{\mathrm{D}}=0.21 \pm\right.$ $0.08 \mu \mathrm{M}$ and $0.28 \pm 0.07 \mu \mathrm{M}$, respectively), suggesting the dominant role of the phosphate moiety. The association and dissociation rates of both were also in good agreement (not shown). An active role of the bactoprenol moiety for friulimicin binding can be excluded, although the relative high binding affinity of FRI-CA to pure DOPC membranes might indicate unspecific interactions with the membrane, most likely via the lipid chain of the peptide. 


\subsection{Role of calcium in the friulimicin binding process}

Since calcium was shown to be essential for friulimicin binding, one might assume that additional calcium ions would further increase binding. Therefore, FRI and FRICA binding to DOPC \pm 0.1 mol\% $\mathrm{C}_{55} \mathrm{P}$ was analysed in the presence of physiological calcium concentrations ( $1.25 \mathrm{mM} \mathrm{CaCl}_{2}$ solution).

Interestingly, this excess of calcium did not improve FRI-CA binding; it even slightly reduced the membrane affinity (not shown). Thus, a peptide-calcium ratio of $1: 2$, as in the case of FRI-CA, appears sufficient to mediate peptide binding. Further calcium ions appear to affect the overall peptide aggregation or directly influence the membrane.

However, the inability of $\mathrm{FRI}$ to bind to $\mathrm{DOPC} / \mathrm{C}_{55} \mathrm{P}$ turned to a moderate binding affinity in presence of $1.25 \mathrm{mM} \mathrm{CaCl}_{2}$ solution $\left[\mathrm{k}_{\mathrm{D}}=1.9 \pm 1.25 \mu \mathrm{M}\right.$; association rate $\left.\left(k_{\text {ass }}\right)=1138 \pm 635 \mathrm{M}^{-1} \mathrm{~s}^{-1} ; \mathrm{k}_{\text {diss }}=1.18 \mathrm{E}^{-3} \pm 0.90 \mathrm{E}^{-3} \mathrm{~s}^{-1}\right]$. Although this affinity is lower than that of $\mathrm{FRI}-\mathrm{CA}$, it indicates that the contact of $\mathrm{FRI}$ with $\mathrm{Ca}^{2+}$ has an evident effect on peptide binding. Different functions of calcium in this process were conceivable. Calcium could mediate the binding of the negatively charged binding partners or could directly affect the peptide and thus enable binding.

The latter became evident by pre-incubation experiments. FRI was pre-incubated in $1.25 \mathrm{mM}$ calcium solution overnight. The binding experiments were subsequently performed in pure aqueous solution. Consequently, remaining calcium had to be in a peptide-associated form. Fig. 1C displays the binding data of pre-incubated friulimicin 
(FRI-PI) to DOPC/ $\mathrm{C}_{55}-\mathrm{P}$ compared with FRI-CA. The association rate $\mathrm{k}_{\text {ass }}$ of $\mathrm{FRI}-\mathrm{PI}$ reached nearly the level of FRI-CA. Overall binding of FRI-PI did not completely attain the levels of FRI-CA, which was mainly caused by a diminished dissociation rate $\mathrm{k}_{\text {diss }}$ for FRI-CA. However, it became evident that calcium affects the peptide before binding to $\mathrm{C}_{55}-\mathrm{P}$, e.g. by mediating the peptide-peptide interaction or by influencing the conformation of the peptide molecules, thus making them accessible for $\mathrm{C}_{55}-\mathrm{P}$ binding. Both possibilities are discussed below.

\subsection{Role of calcium for peptide-peptide interaction}

AFM was used to focus on the role of calcium for peptide aggregation during membrane contact. DOPC forms even and homogeneous membranes (Fig. 2A, left). Addition of FRI or FRI-CA provided identical results. As shown for FRI-CA, both peptides did not influence the DOPC layer but formed giant aggregates of dimension ca. $50 \mathrm{~nm}$ (Fig. 2A, right) that appear to be loosely attached at the membrane and do not reflect the different binding characteristics of FRI and FRI-CA. High-performance liquid chromatography (HPLC) data further confirmed the similarity of the peptide aggregates of $\mathrm{FRI}$ and $\mathrm{FRI}-\mathrm{CA}$ according to their nearly identical elution profiles (30 $\mu \mathrm{g}$ peptide/50 $\mu \mathrm{g}$ buffer) (not shown).

\subsection{Calcium influences the secondary structure of friulimicin}

Since FRI and FRI-CA formed giant aggregates of comparable dimensions, calcium obviously has only a minor influence on peptide aggregation. It might rather influence the conformation of the peptide molecules thus making them accessible for $\mathrm{C}_{55}-\mathrm{P}$ binding. CD measurements were performed using peptide concentrations of $75 \mu \mathrm{M}$ 
and $150 \mu \mathrm{M}$ to determine changes in the secondary structure of friulimicin upon $\mathrm{Ca}^{2+}$ interaction. It became evident that the spectra of FRI, FRI-CA and FRI-PI do not resemble the spectra of conventional secondary structures such as the $\alpha$-helix, $\beta$ sheet, $\beta$-turn or random coil (Fig. 2B). It seems that the friulimicin spectrum is a superposition of two types of secondary structures, but at this stage of the experiments we can neither confirm nor exclude it comprehensively.

The interaction with calcium caused a slight shift $(2-3 \mathrm{~nm})$ of the two maxima (194 $\mathrm{nm}$ and $213 \mathrm{~nm}$ ) towards lower wavelengths. Furthermore, an increase in the amplitude of the signal is observed for the $75 \mu \mathrm{M}$ preparation. Both effects suggest a stabilisation of the peptide secondary structure. Such an increase in the amplitude of the negative $\mathrm{CD}$ signal upon addition of $\mathrm{Ca}^{2+}$ could also be observed for troponin $\mathrm{C}$, reflecting increased stability of the helical regions [10]. Similar findings were reported for daptomycin, where addition of $\mathrm{CaCl}_{2}$ induced an increase in the positive ellipticity maximum and a slight shift from $233 \mathrm{~nm}$ to $231 \mathrm{~nm}$ [11]. However, calcium was also shown to affect daptomycin aggregation [12]. Although the spectra suggest a friulimicin aggregation with increasing peptide concentrations (decreased amplitude for $150 \mu \mathrm{M}$ ), the impact of calcium on this process appears to be negligible. Further CD measurements using a series of friulimicin concentrations confirm that aggregation is mainly a concentration-triggered process (not shown). Nevertheless, the indicated shift in the maxima in the presence of calcium was evident at all concentrations used, especially that at $213 \mathrm{~nm}$. An impact of calcium in mediating a stabilised conformation of friulimicin can thus be postulated and reflects the QCM binding studies. 
This was also confirmed by AFM images. Compared with pure DOPC membranes (Fig. 2A, left), DOPC/ $\mathrm{C}_{55}-\mathrm{P}$ membranes show protruding structures (Fig. 3A), suggesting a clustered arrangement of $\mathrm{C}_{55}-\mathrm{P}$ within the membrane. As observed for DOPC membranes, $\mathrm{FRI}$ attached in an aggregated form to the $\mathrm{DOPC} / \mathrm{C}_{55}-\mathrm{P}$ membranes (Fig. 3B). However, these aggregates appear to be more evenly distributed as a 4-5 $\mathrm{nm}$ layer. It might be assumed that the FRI aggregates accumulate in the areas of the $\mathrm{C}_{55}-\mathrm{P}$ clusters, leading to an even peptide distribution. Nevertheless, this should not be based on a specific recognition of FRI. These aggregates are not the sensitive structures for binding and the density of the layer contradicts a monomolecular association of the peptides to the membrane.

FRI-CA binds at the $\mathrm{C}_{55}-\mathrm{P}$ containing membrane as a thin and dense layer with a detectable surface roughness below $1 \mathrm{~nm}$ (Fig. 3C). No aggregates were detectable. In some areas, height differences of ca. $1 \mathrm{~nm}$ appeared, which should correspond to the surface structures of the DOPC/ $\mathrm{C}_{55}-\mathrm{P}$ membranes. The image refers to a tight peptide binding at the membrane and thus emphasises the present findings on the necessity of calcium and $\mathrm{C}_{55}-\mathrm{P}$ as the target structure for friulimicin membrane interaction.

\section{Conclusion}

The present model membrane approach gives new insights into the antibiotic mode of action of the lipopeptide friulimicin. $\mathrm{C}_{55}-\mathrm{P}$ was clearly confirmed as the target structure by kinetic binding data using QCM. The phosphate moiety of $\mathrm{C}_{55}-\mathrm{P}$ appeared as the essential structure for friulimicin binding. Divalent calcium is essential for this binding process and acts as a bridge between $\mathrm{C}_{55}-\mathrm{P}$ and friulimicin. 
Further focus on the role of calcium in the binding process suggests that calcium has no, or only a minor, effect on the peptide aggregation (AFM images). Nevertheless, CD spectra indicate that calcium indeed influences the conformation of the peptide molecules and obviously shifts the peptide into a suitable form for target binding.

Altogether, the model membrane approach in combination with different analytical tools allow for the first time an insight into the distinct functions of calcium in the antimicrobial activity of friulimicin.

\section{Acknowledgments}

The authors would like to thank Prof. Hans-Georg Sahl for providing the friulimicin peptides. Michaele Joosten is acknowledged for performing the HPLC studies.

\section{Funding}

This work was supported by the German Research Foundation (FOR 854, Be 2242/3-1).

\section{Competing interests}

None declared.

\section{Ethical approval}

Not required. 


\section{References}

[1] Vértesy L, Ehlers E, Kogler H, Kurz M, Meiwes J, Seibert G, et al. Friulimicins: novel lipopeptide antibiotics with peptidoglycan synthesis inhibiting activity from Actinoplanes friuliensis sp. nov. II. Isolation and structural characterization. J Antibiot (Tokyo) 2000;53:816-27.

[2] Bemer P, Juvin ME, Bryskier A, Drugeon H. In vitro activities of a new lipopeptide, HMR 1043, against susceptible and resistant Gram-positive isolates. Antimicrob Agents Chemother 2003;47:3025-9.

[3] Baltz RH, Miao V, Wrigley SK. Natural products to drugs: daptomycin and related lipopeptide antibiotics. Nat Prod Rep 2005;22:717-41.

[4] Silverman JA, Perlmutter NG, Shapiro HM. Correlation of daptomycin bactericidal activity and membrane depolarization in Staphylococcus aureus. Antimicrob Agents Chemother 2003;47:2538-44.

[5] Straus SK, Hancock RE. Mode of action of the new antibiotic for Gram-positive pathogens daptomycin: comparison with cationic antimicrobial peptides and lipopeptides. Biochim Biophys Acta 2006;1758:1215-23.

[6] Wecke T, Zühlke D, Mäder U, Jordan S, Voigt B, Pelzer S, et al. Daptomycin versus friulimicin B: in-depth profiling of Bacillus subtilis cell envelope stress responses. Antimicrob Agents Chemother 2009;53:1619-23.

[7] Schneider T, Gries K, Josten M, Wiedemann I, Pelzer S, Labischinski H, et al. The lipopeptide antibiotic friulimicin B inhibits cell wall biosynthesis through complex formation with bactoprenol phosphate. Antimicrob Agents Chemother 2009;53:1610-8. 
[8] Christ K, Rüttinger HH, Höpfner M, Rothe U, Bendas G. The detection of UVinduced membrane damages by a combination of two biosensor techniques. Photochem Photobiol 2005;81:1417-23.

[9] Christ K, Wiedemann I, Bakowsky U, Sahl HG, Bendas G. The role of lipid II in membrane binding of and pore formation by nisin analyzed by two combined biosensor techniques. Biochim Biophys Acta 2007;1768:694-704.

[10] Smith L, Greenfield NJ, Hitchcock-DeGregori SE. The effects of deletion of the amino-terminal helix on troponin $\mathrm{C}$ function and stability. J Biol Chem 1994;269:9857-63.

[11] Jung D, Rozek A, Okon M, Hancock RE. Structural transitions as determinants of the action of the calcium-dependent antibiotic daptomycin. Chem Biol 2004;11:949-57.

[12] Ho SW, Jung D, Calhoun JR, Lear JD, Okon M, Scott WRP, et al. Effect of divalent cations on the structure of the antibiotic daptomycin. Eur Biophys $\mathrm{J}$ $2008 ; 37: 421-33$. 
Fig. 1. (A) Structure of friulimicin. A cyclic decapeptide is $\mathrm{N}$-terminally linked to an unsaturated branched fatty acid. (B) Binding data for friulimicin (FRI) and friulimicin calcium salt (FRI-CA) to pure 1,2-dioleoyl-sn-glycero-3-phosphocholine (DOPC) and $\mathrm{DOPC} \pm 0.1 \mathrm{~mol} \% \mathrm{C}_{55}-\mathrm{P}$ model membranes. Binding depends on peptide-associated calcium. The target function of the bactoprenol carrier $\mathrm{C}_{55}-\mathrm{P}$ is supported by a six-fold higher binding affinity of $\mathrm{FRI}-\mathrm{CA}$ to $\mathrm{DOPC} / \mathrm{C}_{55}-\mathrm{P}$ membranes compared with pure DOPC. (C) Pre-incubation of pure friulimicin with $1.25 \mathrm{mM} \mathrm{CaCl}_{2}$ solution (FRI-PI) enables the peptide to bind with comparable association constants to FRI-CA. $k_{\text {ass }}$, association rate; $\mathrm{k}_{\text {diss, }}$, dissociation rate; $\mathrm{k}_{\mathrm{D}}$, binding affinity.

Fig. 2. (A) Atomic force microscopy images to illustrate the interaction of friulimicin with 1,2-dioleoyl-sn-glycero-3-phosphocholine (DOPC) membranes: (left) DOPC forms even and homogeneous membranes; (right) both peptides [friulimicin (FRI) and friulimicin calcium salt (FRI-CA)] form giant aggregates of dimension ca. $50 \mathrm{~nm}$ that appear to be loosely attached at the membrane (example shown for FRI-CA).

Calcium obviously does not influence the overall dimensions of the peptide aggregates. (B) Circular dichroism (CD) spectra of FRI, FRI-CA and pre-incubated friulimicin (FRI-PI) at peptide concentrations of $75 \mu \mathrm{M}$ (solid line) and $150 \mu \mathrm{M}$ (dotted line). Compared with FRI, calcium induces a slight shift (2-3 nm) of the two maxima towards lower wavelengths (FRI-CA and FRI-PI), suggesting stabilisation of the peptide secondary structure. The grey lines are drawn at $194 \mathrm{~nm}$ and $214 \mathrm{~nm}$.

Fig. 3. Atomic force microscopy images to illustrate the binding of friulimicin to 1,2 dioleoyl-sn-glycero-3-phosphocholine (DOPC) membranes containing C55-P and the impact of calcium. (A) Compared with pure DOPC membranes (see Fig. 2A, left), the 
$\mathrm{DOPC} / \mathrm{C}_{55}-\mathrm{P}$ membrane displayed structures that suggest a clustered arrangement of $\mathrm{C}_{55}-\mathrm{P}$ in the DOPC membrane. (B) Friulimicin (FRI) attached as large aggregates at these $\mathrm{DOPC} / \mathrm{C}_{55}-\mathrm{P}$ membranes. In contrast to DOPC membranes, these aggregates appear to be more evenly distributed as a 4-5 nm layer. Nevertheless, this should not reflect a specific recognition of FRI. (C) Friulimicin calcium salt (FRI$\mathrm{CA}$ ) binds as a thin and dense layer with a detectable surface roughness below 1 nm. No aggregates were evident. 
A

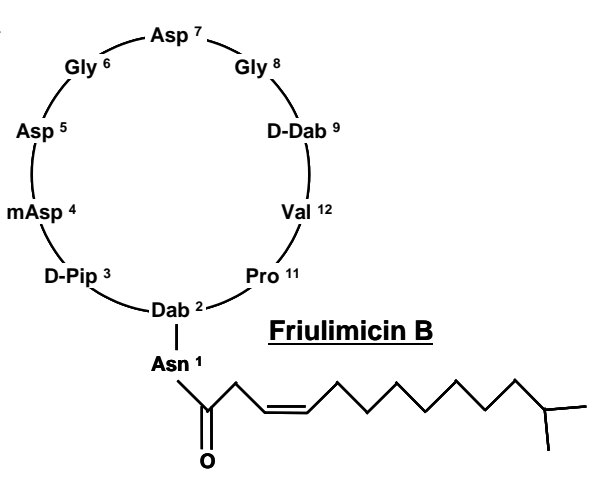

C

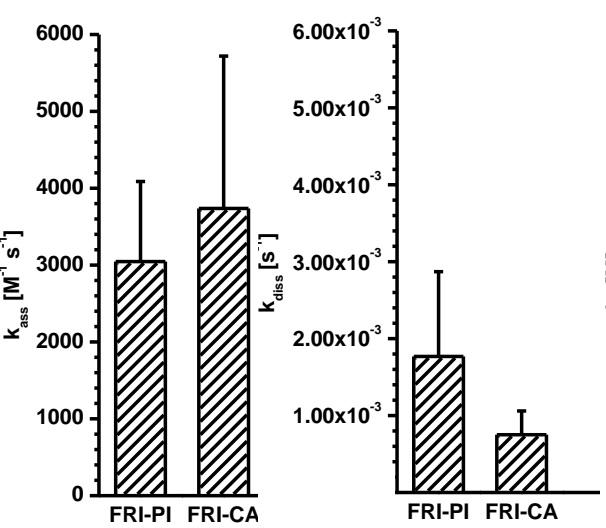

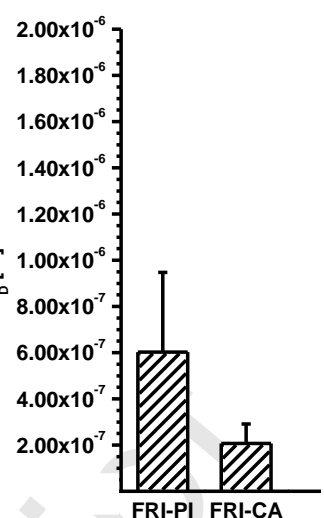

B

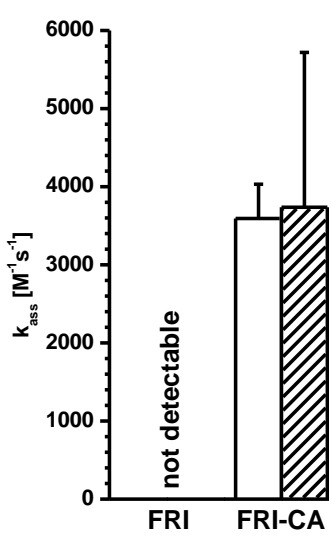

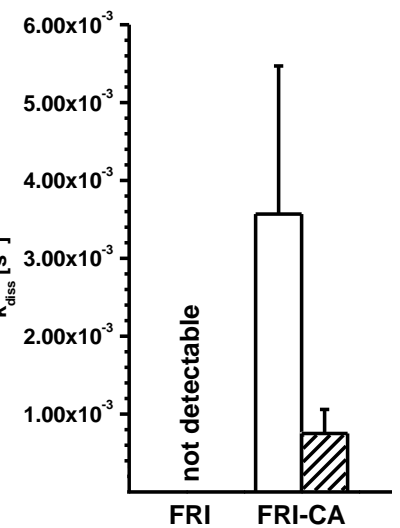

DOPC

ZZZ DOPC/0.1 mol\% 
A

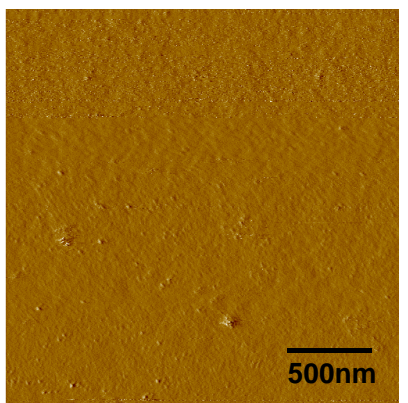

B

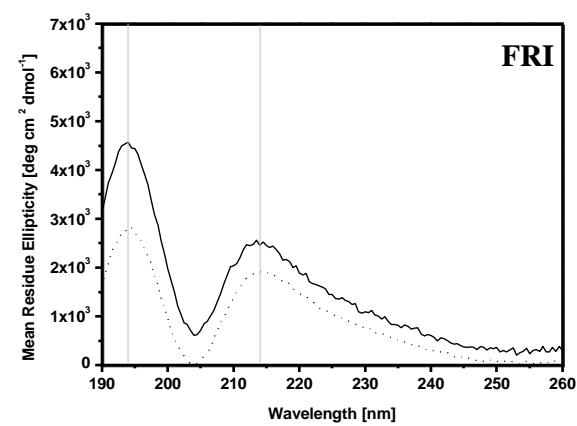

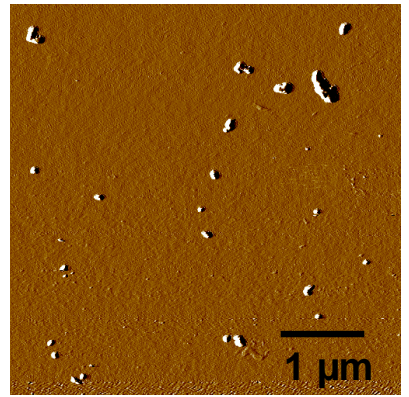
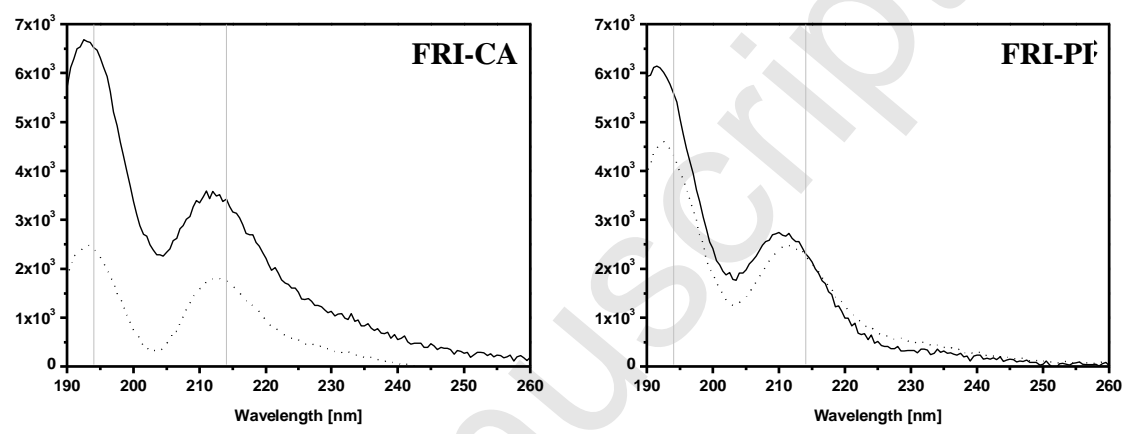
A

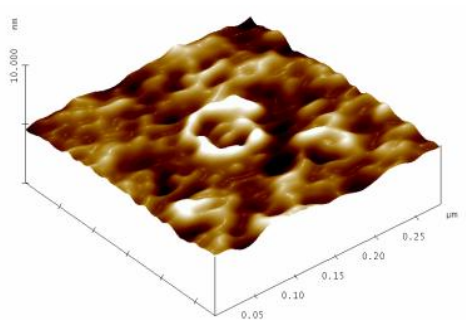

C

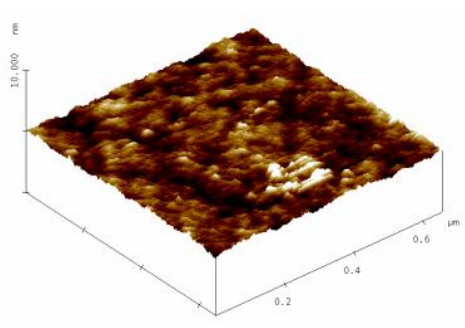

B
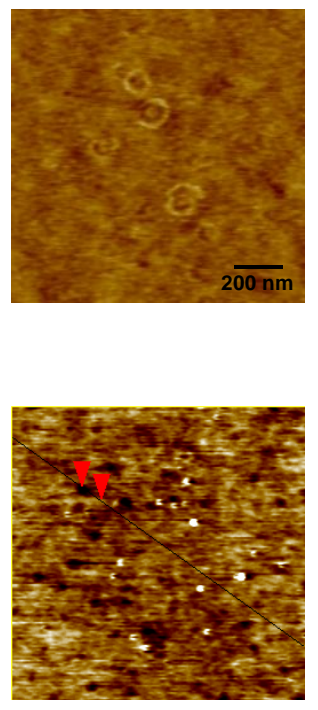

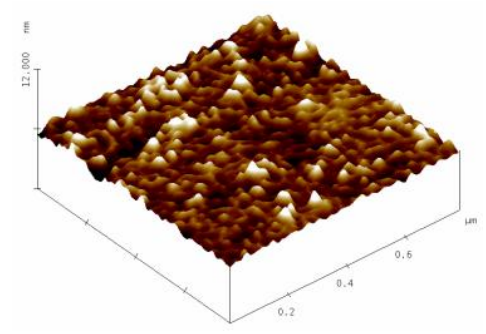

Section Analysis

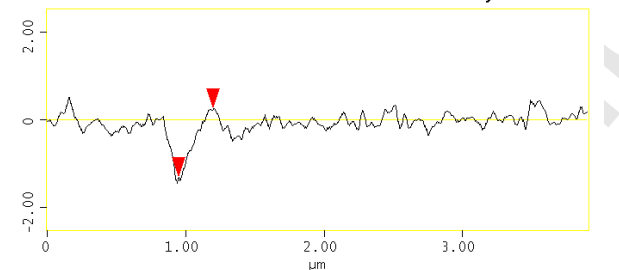

